Rev. Przemystaw Artemiuk Cardinal Stefan Wyszynski University

\title{
A Substantiation of the Historicity of Jesus in Antonio Socci's Apology: A Presentation and Critique
}

In this article, the author presents and critiques of Antonio Socci's substantiations for the historicity of Jesus. This Italian apologist is a writer, journalist, and Catholic publicist is known for his controversial theses. By taking up a defense of Jesus, and thereby Christianity itself, Antonio Socci seeks first to unmask the lies that underpin the foundations of antichristian ideology and then demonstrate the credibility of the events described in the Gospel by referring to archeological and historical studies. As he himself admits, Socci's publications are not the works of an expert, exegete, papyrologist, or historian, but rather the fruit of his journalistic investigations that takes the form of an apology. The author of this article reconstructs Socci's defense of Jesus and then critiques his most controversial theories. He then proceeds to formulate conclusions based on this research.

Key words: Antonio Socci, historical Jesus, apology, sources, substantiation.

\section{Introduction}

By taking up a defense of Jesus, and thereby Christianity itself, Antonio Socci (b. 1959) ${ }^{1}$ seeks first to unmask the lies that underpin the

\footnotetext{
Antonio Socci (b. 1959) is an Italian writer, journalist, and Catholic publicist known for making controversial statements and theories. His most recent publications include: Czas burzy. Dramat czasu konklawe, Kraków 2013; Ci, którzy wrócili z zaświatów, Kraków 2014; Czy to naprawdę Franciszek? Kościót w czasach zamętu, Kraków 2015; Ostatnie proroctwo. List do papieża Franciszka o Kościele w czasach ostatecznych, Kraków 2016; Tajemnica Benedykta XVI. Dlaczego pozostat papieżem?, Kraków 2019; Kościót czasu Antychrysta, Kraków 2020. In this article, I cite excerpts from my book Renesans apologii [The Renaissance of the Apology], Płock 2016, 438-477.
} 
foundations of antichristian ideology and then demonstrate the credibility of he events described in the Gospel by referring to archeological and historical studies. ${ }^{2}$ As he himself admits, Socci's publications are not the works of an expert, exegete, papyrologist, or historian, bur rather the fruit of his journalistic investigations that takes the form of an apology. He admits that he refers to the texts of many specialists

Fundamental Theology in his books, and that he desires to describe the results of their studies extremely accurately. ${ }^{3}$ In his defense of Jesus from the perspective of a journalist, Socci turns to St. Justin Martyr, who made his own defense of Christianity out of love for his Redeemer. The Italian journalist refuses to accept the secular narrative that rejects fidelity to religion and confuses victims with their torturers by comparing the First Christian martyrs to Islamic terrorists, and, instead, strives to reveal truthfully and completely who Christian believers and their Lord and Savior really are. ${ }^{4}$

\section{The Methodological Assumptions of this Research}

The Italian journalist Antonio Socci first became interested in the Master of Nazareth and defending Christ due to Antony Flew's (d. 2010) spectacular conversion. Flew was a philosopher and icon of scientific atheism who, in 2004, publicly declared that he was convinced that God exists ${ }^{5}$ and that the charismatic figure of Jesus deserves attention and demands serious research, because if God has really revealed Himself, then He has certainly done so by taking on the face of Christ. ${ }^{6}$ In this context, A. Socci considers which image of Jesus a researcher who was only now beginning to know the person of Jesus would find. Certainly, such a researcher would have come across a variety of images of Christ, which themselves would be based on interpretations derived from their authors' imagination or beliefs and range from views that reduce Jesus to a myth or completely negate His historicity or existence in general.

$2 \quad$ Cf. J. Kudasiewicz, H. Witczyk, Jezus i Ewangelie w ogniu dyskusji. Od H. Reimarusa do T. Polaka, Kielce 2011, 9-163; Cf. Ł. Wądołowski, Apologia Jezusa $i$ Kościoła w pismach Antonia Socciego, Warszawa 2015, typescript. I. Ramelli (b. 1973), and C. P. Thiede (d. 1952) and unequivocally shares the same point of view.

Cf. A. Socci, Wojna przeciwko Jezusowi, Kraków 2012, 9-15.

Cf. A. Flew, R. A. Varghese, Bóg istnieje. Dlaczego najstynniejszy ateista zmienit swój światopoglad?, Warszawa 2010.

Cf. ibid., 191. 
For the reasons mentioned above, and influenced by intellectuals such as Antony Flew and Rene Girard who converted, Socci seeks to "see, discover, and tangibly touch every trace of Jesus. He confesses that we want to conduct our investigation into Christ as if we were Martians who had just landed on earth. Firstly, we will ask nonChristians, atheists, dissenters, or even enemies of [Christ's] Church about Him."' Thus, Socci's priority is the question of Jesus' identity; he seeks firstly to substantiate this by demonstrating the uniqueness of Jesus' own testimony about Himself, "because He was the only person in history to ever claim that He was God who had become man." ${ }^{8}$ No less important in Socci's work are non-Christian historical documents that testify to Jesus' existence. Socci begins with these in order to respond those who negate that Jesus existed by demonstrating that the Person of Jesus is real and to consider the sources as a whole. This is the approach that A. Socci adopts in his first apology. ${ }^{9}$ First, he tests the credibility of historical sources about Jesus and then shows the Person of the Master of Nazareth in the light of the Gospel by answering the question: "Who is He?"

Why is it so important to return to sources? It is important because people have made claims that deny the historicity of Jesus, and these claims are manifested as ideological arguments against Christianity. ${ }^{10}$ "A. Socci notes that a systematic bloody war has been waged against Jesus for the past three centuries. It is an ideological war in which every tactic is permitted. It is difficult to believe that so few Christians have perceived this, and even fewer have tried to defend themselves against such brutal aggression. A fierce attack on Jesus and His friends-disciples, who, even though were the victims of the authorities and died as martyrs, are now considered frauds and even

$7 \quad$ A. Socci, Śledztwo w sprawie Jezusa, Kraków 2010, 21.

8 Ibid.

$9 \quad$ Taking into consideration the chronology of A. Socci's publications, the exact opposite is true. The Italian journalist first inquires into Jesus' identity (Śledztwo $w$ sprawie Jezusa [2010]) and then examines the sources (Wojna przeciwko Jezusowi [2012]).

10 A. Socci notes that the ideology of suspicion arose during the Enlightenment. Referring only to critical reason, it rejected anything about Jesus that transcended reason, including miracles, divinity, and the resurrection. H. S. Reimarus (d. 1768), G. E. Lessing (d. 1781), D. F. Strauss (d. 1874), E. Renan (d. 1892) and others were proponents of this approach. The doubts that were sown during the Enlightenment later appeared in the philosophical ideas of G. W. F. Hegel (d. 1831), H. Bergson (d. 1941), and J. P. Sartre (d. 1980), who even rejected the historicity of Jesus. Cf. A. Socci, Wojna przeciwko Jezusowi, 253-264, 295-307. 
Fundamental Theology

exalted fanatics who suffered from hallucinations. And here I do not have in mind that about which the rest do not mention-namely, that regimes (Jacobin, liberal, absolutist, fascist, freemason, Nazi, autocrat, democrat, oligarch, Islamic) have persecuted the Church for the past 250 years, which has led to the greatest slaughter in the history of Christianity. No. This is not even about antichristian invectives such as Nietzsche's passionate argument (Antichrist): 'What is more harmful than any vice?-Practical sympathy for the botched and the weak-Christianity....' No. Rather, I am thinking of the ideological attack launched through books (and in collaboration with organizations, academic faculties, magazines, publishers-in short: with the entire influence of the establishment) on the mysterious figure of Jesus described in the pages of the Gospels. That which they call research on the 'Jesus of history' carried out in a spirit of objectivism is, in fact, simple war waged-as Albert Schweitzer admits-with 'hatred' in order to 'strip' Jesus of His divinity and 'place on Him once again the rags in which He walked the paths of Galilee.' Some Catholic exegetes have followed in the footsteps of those who are adept in the art of demythologizing, adopt careless research methods, and are oblivious to the dangers this entails." 11

In view of such allegations, Paul Ricoeur's (d. 2005) statement that "no method is innocent or pure" 12 is important. This is all too clear in the case of enlightened attempts to arrive at a historical Jesus. As Socci notes, hatred for the divine has taken on the appearance of science, which itself has taken on an ideological dimension. Socci notes that "Couchoud's thought that God became man.... irritates us. This is a pre-Kantian idea that was adopted by such famous thinkers as Saint Augustine, Saint Thomas, or Paschal, but yet today it is inconceivable." ${ }^{13}$ A. Socci asserts that, although it takes place on an intellectually and through publications, the war against Jesus wreaks havoc in human souls. "After all, depriving the world of the news that God became man, that He revealed Himself in acts and signs, that $\mathrm{He}$ died for us, also deprives the world of the historical truth about the resurrection and presence of God among us, and it leads to something more than another exegesis or historiography: it leads to desperation. Ideology is the driving force and not the desire to honestly verify the basis on which Jesus of Nazareth claimed to be divine."14

\begin{tabular}{ll}
\hline 11 & Ibid., 83-84. \\
12 & Ibid., 85. \\
${ }_{13}$ & Ibid. \\
${ }_{14}$ & Ibid.
\end{tabular}


How can one overcome the hatred that is, according to Socci, the source of this kind of thinking? Firstly, it is necessary to transcend ideological prejudices and face the facts. Secondly, it is necessary to acknowledge what is impossible in advance and, thereby, transform it into absolute certainty. ${ }^{15}$

In this way, an objective and kindhearted glance at the beginning of Christianity ensures, as A. Socci suggests, that one will arrive at truth. For, observing the extraordinary phenomenon that accompanied the birth of faith in Jesus can bring an encounter with the Master of Nazareth nearer. "Is there any other movement in history whose founder was brutally murdered and whose first spokesmen and all of its most important representatives were martyred, and yet was not only not extinguished but, even more, spread throughout the entire Roman Empire in the course of two centuries? How can this be explained, since the apostles did not take the Roman Empire by force and-like their Teacher-forgave those who persecuted them and, even more: urged their followers to turn the other cheek and repay violence with love? This behavior would be inconceivable except among Christians! Despite persecution, Christianity spread, and today-more than two thousand years later-it is known throughout the whole world. No one questions this fact. Are we not dealing here with an extraordinary phenomenon that deserves deeper consideration? And would it not be reasonable to acknowledge that a series of miracles through which the intervention of some mysterious force can be felt is hidden behind it?"16

By examining Christianity from a paradoxical perspective that precludes merely rational categories and forces one to recognize the phenomenon of Jesus' divinity, Socci does not excuse himself from the obligation to conduct honest research. He indicates, however, that at the origin of faith is an event that cannot be described only as one of many historical facts. For, it is the revelation of God, who became man. Acknowledging this truth helps one understand the history of Christianity, the growth of which—as A. von Harnack (d. 1930) asserts—was

15 “'It all comes down to answering the question: Who is Jesus?' In the history of the world, He was the only one who made such unheard of claims. And, considering that this fact has persisted for more than two thousand years to the present day, the most important thing is to verify its validity. And this [...] can be carried out only by someone who is committed to this search with his whole heart and soul. [...] 'If God exists and if Revelation exists, then He must be it. Only in this does the moving solidarity with what is human appear. Even for the unbeliever, nothing compares with this."' Ibid., 86-87.

Ibid., 88. 
in itself the greatest miracle that occurred without a miracle. ${ }^{17}$ In turn, Socci adopts the following approach to sources: "I want to consider carefully the question of the historical credibility of Christian teaching, which is based on the Gospels. Can we really consider-as the Church has taught for two millennia-that sources about Jesus reliable and historically proven? Or are we dealing with legends, from which min-

Fundamental Theology ute, messy, and uncertain traces of historical truth are drowned in a sea of apologetic, anonymous, and later forgeries? First and foremost, it is necessary to take a look at the witnesses who speak to us from the pages of the New Testament. Are they more credible than the modern thinkers who stubbornly undermine their testimony? Or, are those who wrote the story of Jesus really liars, forgers, and deceivers who only deserve to be forgotten?"18

\section{The Credibility of the Gospel Message}

A. Socci begins his substantiation of the historical credibility of the Gospel by researching eyewitness testimonies. Paschal coined a motto for this process by claiming that we should only believe those stories of witnesses who can be killed (are still alive) (cf. M. 738-739). ${ }^{19}$ Contemporary critics of the Gospel are convinced that these accounts are only testimonies of faith and, for this reason, should be treated in a special way. This also means that they should not be considered credible historical sources and the accounts also do not need to be proven false. Enlightenment thinkers admitted that the "Evangelists acted in good faith, but this (unwelcome) indulgence benefits [such 'thinkers'] more than the Evangelists, for it masks the inability of modernists to formulate serious $j$ 'accuse against these witnesses and prove that they lied. Critics do not take on a challenge that they know will ruin their academic careers (why not?), which seems trivial given that these witnesses were inclined to give their lives for the sake of what they saw and heard." ${ }^{20}$ What do modernist mean, then, when they state that the Gospels are "testimonies of faith"? Does this assertion really mean that they consider them forgeries, legends, arbitrary, or lacking in objectivity? The Italian journalist notes that proponents of this theory blame the evangelists for writing false accounts of Jesus' life that are influenced by their personal experience of faith, but they do

\footnotetext{
17 Cf. ibid., 89.

18 Ibid.

Cf. ibid., 90; B. Pascal, Myśli, ed. T. Żeleński (Boy), Warszawa 1989, 392-393. 
not substantiate this claim. In the absence of the critics' arguments as well as "in the absence of any clear deception and evident forgery, all seriousness and honesty would demand that the Gospels be treated like any other text-that is, considered as historical sources and verified documents." ${ }^{21}$ A. Socci adds that the Enlightenment paradigm should be shifted completely and states that the Gospels are "evidence of existing facts," and not "evidence of faith." 22 For, faith arises only after an encounter with the facts. "In other words, the twelve apostles Theology did not realize that they were seeing and touching the Risen [Christ] because they were being guided by faith; on the contrary, they believed precisely because they-going against their initial doubts-saw and touched the hand of Jesus, who had died on the cross barely three days before. Moreover, they spoke with Him and ate fish with Him several times. They had to capitulate to what was obvious, which they refused to acknowledge at first and which they firmly rejected because they were convinced that they were seeing a ghost. The certainty that Jesus rose from the dead was the result (and not the cause) of their shocking experience of seeing and touching [Him]. This is also applies to their testimonies. After all, they announced to the world something that was not only shocking (the crucified Redeemer, the death of the damned) but also foreign and even blasphemous to their Jewish way of thinking: the achievements of a Man who calls Himself God and who really is God (true Man and true God)."23

A. Socci notes that experiences of the Master's presence (i.e., the experience of encountering Him and speaking about this encounter; i.e., giving testimony) are palpable on the pages of the New Testament. The protagonists of these writings "firmly and consistently emphasize the significance of what happened and what they saw with their own eyes, and they proclaim this faithfully without adding or redacting anything. As witnesses, they proclaim the truth openly and expose themselves to every kind of criticism (if it were to turn out that they were lying) and persecution by their enemies (who were numerous, vehement, and included the influential family of Caiaphas, who tormented Jesus' followers after His crucifixion)." ${ }^{24}$ Socci emphasizes that the Twelve Apostles as well as Jesus' other followers were not preachers and much less those who wanted to create a new religion, but rather "witnesses to a series of events who had no intention of

\begin{tabular}{ll}
\hline 21 & Ibid., 92. \\
22 & Cf. ibid., 93. \\
23 & Ibid., 93-94. \\
24 & Ibid., 94.
\end{tabular}


Fundamental Theology

remaining silent about what they saw." 25 The later texts of the Gospels are based on their testimony. "The Letters, Acts of the Apostles, as well as the remainder of the New Testament are nothing other than a proclamation: 'We really heard Him and we really saw Him!' If this was really about a symbol, then why would the authors have to repeat so often and so emphatically that they are "testifying." 26 This emphasis is characteristic of the canonical writings and is not found in the Apocrypha. "The persistence about things seen, heard, and touched is seen only in the texts recognized by the Church and proves that they are not second or even third hand accounts written by anonymous authors who tell folk legends and who color them with stories about miracles. No- the apostles go to the town squares and synagogues in order to proclaim their teachings in the presence of the leaders just like eyewitnesses give testimony in court. This makes what they say credible and refers to Jesus, who thousands of people knew, heard, and observed, including the dignitaries who condemned Him to death. Every person who found himself in Jerusalem at that time could have seen with his own eyes the empty grave into which Jesus' body was placed." 27

Jesus' followers reported what they had seen and touched. They did not cower before threats or even martyrdom because their Master had warned them beforehand that these things would occur. By choosing to remain with Christ, they left everything and (not without some fear) gave themselves completely to their Teacher, who had chosen them Himself. After Jesus rose from the dead and sent them out, they began their mission to preach in His name. "Their credibility as witnesses is extraordinary, undeniable, unique, and above all 'confirmed' by the miracles that Jesus performed through them." ${ }^{28}$ It is for this reason that A. Socci emphasizes that "it would be impossible to find elsewhere the historical facts about which these witnesses testified. The credibility of Jesus' friends is truly incredible. Their moral dimension is immeasurable and their honesty surpasses that of the modern rationalist thinkers who call it into question." 29

Why, therefore, has their testimony been called into question in modern times? A. Socci states that, in the case of Jesus and His followers, modernists do not consider the generally accepted criteria of

\begin{tabular}{ll}
\hline 25 & Ibid., 97-98. \\
26 & Ibid., 100. \\
27 & Ibid., 101. \\
28 & Ibid., 106. \\
29 & Ibid., 108.
\end{tabular}


rationality and historiographical correctness applicable. Instead, Jesus and his followers are distrusted and approached with the assumption that lying is the norm. And, even though, the basic principle of historiography is 'in dubio pro tradito,' this rule does not apply to Christ. This approach assumes that one is not able to use the same means to study ancient history (e.g., Greek or Roman) as Christianity. According to rationalist researchers, it is difficult to strictly call the Gospels or New Testament sources. How, then, can their credibility be substanFundamental tiated? A. Socci firstly states that historiography incomprehensibly and unfoundedly discriminates against the New Testament. When researchers consider the Gospels, they do not pay attention to logic or their own classical rules. Modern historiography is extraordinarily prejudiced against the history of Jesus, and, yet, in "the Gospels and the Acts of the Apostles, such terms as 'witness' (martyrs) and 'testimony' (martyrion) are used in the 'classical oratory and judicial' as well as the 'Greek historiographical' sense-which makes sense if you take into consideration the fact that the apostles had to testify before judges." ${ }^{30}$ Furthermore, substantiating the credibility of Christian sources must include the assertion that "the evangelists' intentions were to describe Jesus' works in a manner proper to chroniclers and historians by emphasizing facts." 31 The purpose of the Gospels was to gather and transmit the testimonies of the disciples-those who accompanied Jesus. "Therefore, it is obvious that they were neither written nor prepared like typical books; for, the testimonies of eyewitnesses serve as the groundwork. Living testimonies were and continue to be the most important, and the Church faithfully transmits them." " ${ }^{33}$ The eyewitness serves as the greatest guarantor of the Gospels' credibility. Fathers of the Church such as Papias (d. cir. 130 AD) or Irenaeus (d. cir. 200 AD) confirm this, but other works such as the apocryphal Acta Petri (150 AD) also focus on the importance of eyewitnesses. It, therefore, can be said that both written and orally transmitted texts had to be confirmed by eyewitnesses, and only then were they considered credible. ${ }^{34}$

In the second stage of his substantiation, A. Socci's points out the distinction between the inspired writings and the definitive emergence of the New Testament canon. The person of Jesus, after all,

\begin{tabular}{ll}
\hline 30 & Ibid., 110. \\
31 & Ibid., 111-112. \\
32 & Cf. ibid., 113. \\
33 & Ibid. \\
34 & Cf. ibid., 113-114.
\end{tabular}


Fundamental Theology

appears in many early Christian writings, which leaves one to question how the books of the canon were chosen. In making this distinction, Socci indicates that "they did not take only the purity of the text into consideration; it was also important that the [texts] were completely faithful to the facts. For example, the orthodox work such as the Protoevangelium of James, which admittedly relates events from the past but is primarily a literary work filled with poetry and symbols, was not included in the canon." 35 When selecting the books, truth about events was important and any distortions or false threads were thrown out. In addition, the authorship of the apocryphal books was verified. Faithfulness to the original message based on the words of witnesses is clear in the case of the canonical Gospels. "Each individual [Gospel] has its own emphasis that differentiates it from the others. The culture and spirituality of each author left its mark on the texts (which is further evidence that the Gospels are the works of particular authors and not anonymous communities)." ${ }^{36}$ And while the Gospels agree about key moments in Jesus' life, they differ in the details and contain troublesome differences. These differences were never discarded and testify to Gospels' authenticity. This is clear, for example, in the account of the empty tomb. "A single event occurred, and everyone agrees on this, but every person found out about what happened in a different way. The gospels-precisely because they are authentic testimony and not carefully thought-out fiction-reflect subjective perceptions of what occurred after the resurrection. As Thucydides taught, precisely this subjectivity and chaos are the hallmark of authentic, real-life stories and prove that they are truthful." 37 Thus, troublesome details and discrepancies only strengthen the credibility of the Gospels.

Ibid., 115. The Gospel of James is an apocryphal text that was written in the middle of the second century; for this reason, it is difficult to consider it canonical. "As M. Starowieyski notes, it seems that the author was from JudeoChristian circles, which is confirmed by the work's features-midrash and the references to James the Less and other figures who were respected greatly in Judeo-Christian circles. The goal of the work is fourfold: apologetic-Christological, dogmatic, biographical, and exegetical. The Gospel of James 'is a Marian Christian midrash. The plot is based on the descriptions of Jesus' birth in both Gospels (Matthew and Luke), which is based on figures from the Old and New Testaments: from the stories of Samuel, Abraham, Tobias, and Judith, and contains references to the exegetical views of that time, which we encounter in the Talmud and the intertestamental writings." Apokryfy Nowego Testamentu. Ewangelie apokryficzne, ed. M. Starowieyski, vol. 1, http://www.opoka.org.pl/ biblioteka/T/TB/apokryfy-04.html. Accessed 11.25.2020.

A. Socci, Wojna przeciwko Jezusowi, 116.

Ibid., 122. 
To prove the authenticity of the Gospels, Socci focuses on the languages in which they are written and uses it to determine when and who wrote them. His research is written for one purpose only-namely, to abolish modern theories that not only reject the authorship of Matthew, Mark, Luke, and John but also seek to force their own ideological constructions on the Gospels and claim that the New Testament Books were written later in order to abolish the fact that the events occurred. "For centuries, the multitude of sources has proved that the Gospels were written shortly after the events they relate, around 40 or $50 \mathrm{AD}$. For seventeen centuries no one has dared to question this historical fact. However, the rationalist school tries at all cost to refute this proven thesis, and, insofar as new historical, archaeological, and philosophical discoveries do not prove otherwise, they rely on a predetermined scheme and begin instead where they should end up. In other words, they assert that, because miracles do not exist, the Gospel writers described them at a point when no one was around to contradict them, specifically after the [siege of Jerusalem] that occurred in $70 \mathrm{AD}$, after which Jesus' contemporaries and all of Jerusalem ceased to exist." 38

How can this thesis be refuted? A. Socci first points to the language of the Gospels. The Gospels have survived until modern times in Greek, which was commonly used, even in Palestine, at the time they were written. Twentieth-century biblical studies have revealed

$38 \quad$ Ibid., 302-303. The Polish biblical scholar M. Wojciechowski (b. 1953) points out that the Synoptic Gospels were being written "at the end of the Apostles' lives or shortly before their death, at a time when the Greek-speaking Church was rather quite developed. The Gospels were a response to a new situation in Christianity; those who had witnessed Jesus' life were about to depart this life, and they needed to record what they remembered about him. This occurred sometime between 60-100 AD. It is difficult to date the works more accurately. The Gospels were not written during the second century because they were already in existence and being cited at that time [...] The St. Mark's Gospel is considered the oldest, and it served as a model and source for the other Gospels. If it was written close to the end of St. Peter's life or after, then it was likely written sometime between 60-70 AD. One can observe that Mark's Gospel lacks allusions to the fact that the Romans had conquered Jerusalem, which is where nearly half of the Gospel accounts take place, and burned down the Temple. At the same time, Mark's Gospel speaks clearly about the threat looming over Jerusalem (Mk 13). This too corresponds to the years just before $70 \mathrm{AD}$. If the Gospels of Matthew and Luke were written after, then it would have been after $70 \mathrm{AD}$. Scholars have pointed out that Jesus' prophecy about the calamities that would befall Jerusalem (Mark 13 and others) is rather general, whereas the Gospels of Matthew (22:7) and Luke (21:20, which includes terms pertaining to the siege) contain allusions to the Roman conquest of Jerusalem in 70 AD. This indicates that those Gospels were written in the wake of the events that took place in 70 AD." M. Wojciechowski, Czym sa Ewangelie, Kraków 2014, 53-54. 
Fundamental Theology

beyond a doubt that "the Greek text is a translation of the original Semitic language. Some contemporary scholars even claim that the evangelists used the notes that the apostles took in Aramaic while Jesus was teaching, which was a fairly widespread practice at the time among those who listened to rabbis." ${ }^{39}$ Therefore, according to this assumption, the Gospels were written shortly after Jesus' crucifixion, and the Greek text is the translation of the Semitic original, which, according to J. Carmignac (d. 1986), means that the there is a Semitic spirit hidden in the body of the Greek text. ${ }^{40}$ In turn, Socci quotes C. Tresmontant (d. 1997), who thinks that pagan Hellenist communities did not write the Gospels because the members of these communities did not know Hebrew. The effort that Socci makes to substantiate this thesis aims to show that the original Gospels were written much earlier than rationalist exegetes claim and in a Semitic language other than Greek, which is full of ambiguities, anomalies, and discrepancies. ${ }^{41}$ Socci ultimately shares the same point of view as J. Carmignaca, who considers the Gospels as "the testimony of eyewitnesses written shortly after the events they describe." ${ }^{42} \mathrm{He}$ adds a very eloquent punch line: "Today, after twenty centuries have passed, and without any historical, philosophical, or archeological arguments, calling the authorship of the Gospels into questions appears to be a grim and purely ideological approach: I have the impression that they try to separate the evangelical stories from the eyewitnesses and historical references at all cost. Meanwhile, the document are very clear in this regard, including those written by the first generation after the apostles: from Papias of Hierapolis (who carefully examined the Jesus and the apostles' milieu) to Justin, from Irenaeus to Tertullian, and from Origen and Clemente of Alexandria to Eusebius of Caesarea." 43

When speaking about the sources that pertain to Jesus, A. Socci points to the first early Christian writings. Although they are not inspired texts, they do play an important role in substantiating the

A. Socci, Wojna przeciwko Jezusowi, 309-310.

Cf. ibid., 310. A. Socci describes Fr. J. Carmignac's studies accurately and focuses on many detailed issues; Cf. ibid., 310-324; Cf. J. Carmignac, Poczatki Ewangelii synoptycznych, Kraków-Mogilany 2009.

\section{Cf. A. Socci, Wojna przeciwko Jezusowi, 323.}

Ibid. According to J. Carmignac, St. Luke and St. Matthew's Gospels were written in Greek no later than 50-53 AD. St. Mark's Gospel was written in Hebrew sometime between 42-45 AD. For a detailed discussion of the chronology and authorship of the Gospels, see Ibid., 347-397.

Ibid., 378; A. Socci notes that the discovery of the Dead Sea Scrolls confirm these findings. The Italian journalist discusses this in detail in Ibid., 402-443. 
credibility of the person of Jesus. Among others, they include: The Didache, meaning The Teaching of the Twelve Apostles, the Epistle to the Philippians by Polycarp of Smyrna, The Shepherd of Hermas, the so called Epistle of Barnabas, Epistle of Diognetus, The Fragments of Papias, and Justin's Apology. ${ }^{44}$ All of these writings appear shortly after the death of Christ-at the end of the first or the beginning of the second century - and are unique documentation. "We are convinced of this after comparing Christ to other historical figures." 45 The first Fundamental mention of Herodotus (d. 425 BC) appeared around 100 years after his death in the Aristotle's (d. $322 \mathrm{BC}$ ) writings and 400 years after in Cicero's (d. 43 BC) writings. In turn, by comparing Jesus with Alexander (d. $323 \mathrm{BC}$ ), the Macedonian appears in the historiography only 400 years after his own death. The contemporaries of the Master of Nazareth, including Flavius Josephus (d. cir. 100 AD) or Philo of Alexandria (d. cir. 45/50 AD) who were all notable figures of the first century do not appear in Hebrew tradition during this time. Therefore, when compared to that of other men, the documentation on Jesus is impressive. However, Socci notes that, in Jesus' case, "the classic criteria of historiography do not apply because, although we are dealing with credible texts that were written by extremely credible authors, they not considered 'source materials' and are relegated to the category of the 'first Christians' expressions of faith."' 46

So, are we really dealing with silentium saeculi in Jesus' case? If the Christian authors are not considered historiographically credible, then who can we invoke as a witness of Jesus?

\section{A Critique of "Questionable" Non-Christian Sources}

A. Socci points out much of the Roman literary legacy pertaining to the Master of Nazareth has not survived to this day. For example,

$44 \quad$ Strictly speaking, the writings that A. Socci mentions are primarily the works of the Apostolic Fathers (except for St. Justin's Letter to Diognetus and Apology). As H. Pietras (b. 1954) indicates, they were "the oldest Christian writers, witnesses of apostolic tradition, the disciples of the apostles, or at least the disciples of the apostles' disciples. Although not included in the New Testament canon, their writings arise from the same experience of faith in the Risen Christ and supplement the biblical message. The concept of Apostolic Father was introduced in the $18^{\text {th }}$ century"; Idem, Poczatki teologii Kościoła, Kraków 2007. The Italian journalist should mention additional works of the Apostolic Fathers-namely, Clement of Rome's Letter to the Corinthians as well as Ignatius of Antioch's The Seven Epistles and The Martyrdom of St. Polycarp.

A. Socci, Wojna przeciwko Jezusowi, 126.

Ibid., 127. 
the work The Chronicle of the Kings of Israel by Justus of Tiberias (d. $100 \mathrm{AD}$ ), which tells the history of the Judean rulers from the time of Moses to Agrippa II, has disappeared. In addition, only of few of the Annals written by Tatius (d. cir. 120 AD) have survived. His book detailing the years from 29-32 AD that would contain possible descriptions of Jesus' public activity are lost, and Book 16 ends at year 66 AD. The loss of these books can be attributed to the fact Vespasian (d. 79

AD) and Hadrian (d. 138 AD) ordered all archives in Jerusalem to be burned. ${ }^{47}$ What, then, can we learn about Jesus from pagan sources?

In his Annals, ${ }^{48}$ Tacitus relates that a fire occurred in Rome in 64 $\mathrm{AD}^{49}$ and that Nero sought to find the party who was responsible for the disaster. A passage from Book XVI relates that Christians were living in the Eternal City and how the Roman's perceived them. ${ }^{50}$

$47 \quad$ Cf. ibid., 128-129.

48 This work was written at the beginning of the second century (110-116 AD?) and covers the time from the death of August (14 AD) to $68 \mathrm{AD}$ (the beginning of the Acts of the Apostles). The Annals are comprised of 18 books, of which Books I-IV have been preserved in their entirety, Book V been preserved in fragments, Book VI lacks a beginning, and Books XI-XVI are also incomplete.

"There followed a disaster, whether due to chance or to the malice of the sovereign is uncertain - for each version has its sponsors - but graver and more terrible than any other which has befallen this city by the ravages of fire. It [the fire] took its rise in the part of the Circus touching the Palatine and Caelian Hills..."; Tacitus, Book XV, Par. 38, Annals. English translation can be found at:https://penelope.uchicago.edu/Thayer/E/Roman/Texts/Tacitus/Annals/15B*. html Accessed 12/08.2020.

50 "But all human efforts, all the lavish gifts of the emperor, and the propitiations of the gods, did not banish the sinister belief that the conflagration was the result of an order. Consequently, to get rid of the report, Nero fastened the guilt and inflicted the most exquisite tortures on a class hated for their abominations, called Christians by the populace. Christus, from whom the name had its origin, suffered the extreme penalty during the reign of Tiberius at the hands of one of our procurators, Pontius Pilatus, and a most mischievous superstition, thus checked for the moment, again broke out not only in Judæa, the first source of the evil, but even in Rome, where all things hideous and shameful from every part of the world find their centre and become popular. Accordingly, an arrest was first made of all who pleaded guilty; then, upon their information, an immense multitude was convicted, not so much of the crime of firing the city, as of hatred against mankind. Mockery of every sort was added to their deaths. Covered with the skins of beasts, they were torn by dogs and perished, or were nailed to crosses, or were doomed to the flames and burnt, to serve as a nightly illumination, when daylight had expired. Nero offered his gardens for the spectacle, and was exhibiting a show in the circus, while he mingled with the people in the dress of a charioteer or stood aloft on a car. Hence, even for criminals who deserved extreme and exemplary punishment, there arose a feeling of compassion; for it was not, as it seemed, for the public good, but to 
The book also mentions the how this religious group originated in Palestine. Tacitus knows who Jesus is and what happened to Him. A. Socci suggests that the Roman historian obtained his knowledge about Jesus from credible sources such as, for example, the minutes taken during the meetings of the Senate. ${ }^{51}$ Notes about the Rabbi from Palestine could be found in these minutes because Tiberius Caesar presented a proposal before the Roman assembly to legalize the new "Christian" religion and recognize Jesus as "god" in $35 \mathrm{AD}$. Fundamental Is this the true version of what happened? "Taking into consideration the policy that Tiberius pursued in Palestine, this proposal must be considered credible in every way; the legalization of this new Jewish 'heresy' was guided by the same goal behind the imperial policy that sought to remove Samaritans from the protection of Judea and make them Rome's allies." 52 The Italian journalist adds that Tiberius Pilate could have been the source of information about Jesus because he made recommendations to Tiberius Caesar in favor of the Christians. Unfortunately, the governor's account was lost, which leaves one to draw a hypothetical conclusion that, however, is not unfounded. Italian historians, whose research Socci takes pains to describe precisely, confirm this version of events based on the accounts Sts. Justin ${ }^{53}$ and Tertullian's ${ }^{54}$ accounts, the Nazareth stone inscribed with an imperial edict, and primarily the acts of the Senate, ${ }^{55}$ specifically the noteworthy senatus consultum from $35 \mathrm{AD}$, which is so adverse and problematic to modern critics that it was silenced and suppressed. It is this document that presents information about Jesus' resurrection as a real

glut one man's cruelty, that they were being destroyed"; Tacyt, Wybór pism, ed. S. Hammer, Wrocław 2004, 190-191. Ibid., 136.

A. Socci refers to the historian, Marta Sordi, who found traces of evidence in St. Justin's writings that Tiberius Caesar proposed legalizing Christianity. In reality, however, Justin's Apology contains no evidence of Tiberius' plan. Cf. Justyn Męczennik, "1 Apologia 1.1-13.1," in: Justyn Męczennik, 1 i 2 Apologia. Dialog z Żydem Tryfonem, trans. and comp. L. Misiarczyk, Warszawa 2012, 43-50.

As Tertullian asserts, "Tiberius accordingly, in whose days the Christian name made its entry into the world, having himself received intelligence from Palestine of events which had clearly shown the truth of Christ's divinity, brought the matter before the senate, with his own decision in favour of Christ. The senate, because it had not given the approval itself, rejected his proposal"; "Apologetyk", vol. 2, in: Pisma Ojców Kościoła, vol. 20, ed. J. Sajdak, Poznań 1947. 
Fundamental Theology

and actual event, and not as a myth. ${ }^{56}$ Tertullian confirms this and considers Tiberius a defender of Christians. ${ }^{57}$

When evaluating Tacitus' account and A. Socci's interpretation of this source, it is clear that the Italian apologist's conclusions go too far. The Roman historian's account regarding Christians is certainly based on his personal experience in the proconsul as well as other historical documents such as the minutes taken during senate meetings of the Roman Senate. Without access to these documents, it is impossible to recreate Tiberius' relationship to Christians much less to study how the acts influenced Tacitus' writings. It is difficult to build an argument on circumstantial evidence as A. Socci does. As M. Skierkowski notes, Tacitus' testimony "may be independent," not refer to the New Testament. However, Socci's search for deeper connections appears to be over interpretation.

According to Socci, Seneca's (d. 65 AD) Letters to Paul, which were once considered Apocrypha, are another historical source about Jesus. ${ }^{59}$ Recalling this epistolary work, the Italian apologist notes that it demonstrates excellent knowledge of the chronology of Paul's works and is a very personal account, which is evident in the apostle's concern about the fate of his Roman friend, as well as Seneca's curious

Cf. ibid., 137.

A. Socci states that Tertullian "encouraged readers to study historical books (the books of the Senate) and make certain that, the degree to which Tiberius protected Christians was the degree to which Nero was the first [...] to wield the emperor's sword against this community that had spread so widely throughout Rome"; Ibid., 149-150.

K. Obrycki (b. 1941 points out that “The Seneca and St. Paul's correspondence is one of the mysterious memorials of ancient Christian literature. The Church fathers were interested in it and, until our modern times, it has piqued the intellectual interest of researchers. Because of the authority of two Doctors of the Church-namely, St. Jerome and St. Augustine-the authenticity of this correspondence was never called into question and, [when it was called into question] these inquiries were dismissed on the basis that the correspondence is universally recognized as authentic. Exegetical and stylistic studies that have been conducted since the middle of the $15^{\text {th }}$ century, when Italian humanists raised doubts about the correspondence's authorship, led in time to the work being recognized as apocryphal. Throughout the Middle Ages and up to modern times, scholars were convinced that Seneca had met St. Paul and, through him, was introduced to Christianity. Different arguments were made to confirm that the Apostle to the Nations had known Nero's educator and make sense of their supposed friendship"; "Apokryficzna korespondencja między Seneką i świętym Pawłem," trans. and ed. K. Obrycki, Warszawskie Studia Teologiczne 10(1997): 219. 
relationship to the Master of Nazareth. He was "undoubtedly enamored by the noble figure of Jesus as well as by a 'philosophy' that, through Paul, became a new way of being and living. Along with Christianity, new moral norms that were heretofore unthinkable (particularly to the stoic milieu) arose." ${ }^{\circ 0}$ Seneca must have encountered Christianity earlier, but his friendship with Paul deepened his fascination with it. The historians to who Socci refers ${ }^{61}$ emphasize that this fascination is evident in Seneca's works. The stoic discovered the one paternal Fundamental God, declared his faith in Him, and was convinced that this faith was the only thing that gives human life meaning. The passages that refer to Christianity most clearly appear after $62 \mathrm{AD}$, when the philosopher had withdrawn completely from his involvement in politics. In many passages, you can feel the Paul's inspiration as well as references to the Gospel. These Christian accents confirm only that Seneca must have been familiar with Christianity and that he had a great respect for it. ${ }^{62}$ At times, the reader may have the impression that the philosopher had not only classical sources but also the Gospels on his desk when he was writing his tragedies (Hercules Oetaeus and Hercules Furens). "It is difficult to believe that such evident 'carbon copies' of Christian texts has escaped the notice of the critics, or that they failed to mention them."63

The fact that Socci considers Seneca's correspondence with Paul a source that indicates the historicity of Jesus raises some fundamental doubts. As historians have shown, this work is undoubtedly a pseudocorrespondence. As the classical philologist M. E. Szarmach (b. 1939) indicates: "Christians piously wish that some kind of contact existed between these two notable figures that resulted a correspondence that is Apocrypha. These fourteen letters - eight of which Seneca wrote to St. Paul, and six of which St. Paul wrote to Seneca, which are often only notes, are known today primarily by classical philologists. Some of them can be dated according to when certain Roman consuls were in power. A careful examination of the dates indicates that they are fictional." ${ }^{44}$ St. Jerome (De viris illustribus 12) and St. Augustine (Letters 153.14) do not confirm the authenticity of these letters; rather, they only confirm that such correspondence exists. Apocrypha from the

A. Socci, Wojna przeciwko Jezusowi, 153.

E. Grzybek, M. Sordi, I. Ramelli, and C. P. Thiede.

Cf. A. Socci, Wojna przeciwko Jezusowi, 164.

Ibid., 166.

$64 \quad$ M. Szarmach, “'Listy, które czyta wielu:' Psuedokorespondencja św. Pawła z Seneką,"Symbolae Philologorum Posnaniensium Graecaeet Latinae 22(2012): 92.
} 
Fundamental Theology

fourth and fifth centuries such as Passio Pauli Apostoli ${ }^{65}$ as well as other later writers ${ }^{66}$ refer to the correspondence. It has been determined that the work was written sometime between $324 \mathrm{AD}$ (terminus post quem-in Divinae Institutiones, Lactantius writes favorably of Seneca but does not mention anything about his correspondence with St. Paul) and $392 \mathrm{AD}$ (terminus ante quem-in On Illustrious Men, St. Jerome mentions the letters when he writes about Seneca). It continues to be difficult to establish who wrote the letters. Philologists surmise that a group of rhetoric students wrote the correspondence because of its "curt style, grammatical awkwardness, and poor content." ${ }^{67}$ For this reason, Seneca's correspondence with St. Paul cannot be considered a credible source that confirms the historicity of Jesus.

Socci also points to the Roman writer, politician, and philosopher Gaius Petronius (d. 66 AD), who replaced Seneca after Seneca fell out of favor with Nero as arbiter elegatniae (until $65 \mathrm{AD}) .{ }^{68}$ When reading Gaius Petronius' works, one can ascertain that the figure of Jesus and His works were known in Rome and that Christianity was heated topic of discussion before 68 AD. Both Petronius' Satirycon, ${ }^{69}$ which

65 Cf. K. Obrycki, ed., trans. "Apokryficzna korespondencja między Seneką i świętym Pawłem,” Warszawskie Studia Teologiczne 10(1997): 220.

66

Ibid., 220-222.

Ibid., 224.

"Petronius (Caius Petronius Arbiter) is a first-century Roman writer and poet. He wrote the realistic Roman romance Satyricon, which is comprised of 20 books, and in which he parodied Greek romance and included a witty description of Trimalchio, the wealthy former Roman. Nero favored Petronius and considered him an authority in art and elegance (he was called arbiter elegentiarum). In 65 $\mathrm{AD}$ he was accused of being involved in the Pisonian Conspiracy and forced by Nero to commit suicide. The longest of the preserved passages is "The Banquet of Trimalchio"; Stownik kultury antycznej, ed.L. Winniczuk, Warszawa 1988, 37.

No one is certain whether Gaius Petronius wrote this work. L. Staff states that "We know from is work only that he was a man of high education and great talent and wit, and an excellent observer of southern Italian attitudes; other than this, we cannot know anything for certain. Manuscripts call him Petronius Arbiter. History has recorded the names of approximately twelve Petroniuses who distinguished themselves in the fields of literature, philosophy, astrology, and administration; one of them was the Bishop of Bologna. The author of Satyricon could have been Gaius Petronius, who belonged to Nero's close circle of advisors and who Nero forced to commit suicide in $66 \mathrm{AD}$, meaning 819 years after Rome had been founded. In his Annals (XVI.16 and the following), Tacitus relays that Petronius dedicated the day to sleeping and the night to his social obligations and pleasures. He was known for his laziness in the same way that others were known for their industriousness... He earned the title of master of the art of use... Despite this, when he became Proconsul of Bithynia and then the Consul, he proved to be energetic and brave... He was Nero's trusted friend. 
was written in 64-65 AD, and The Banquet of Trimalchio correspond to the Gospel, and the author's intention was "to present to the emperor a series of scathing parodies of the life of Jesus."70 In his parodies, Petronius clearly refers to Christian motifs. For example, the name Trimalchio is a Semitic word that means "the threefold king." Could this be a reference to the Holy Trinity? Moreover, in Satirycon, which is filled with allusions, there is a parody of the "anointing in Bethany." As Socci points out: "Trimalchio envisions his own death and the funeral while simultaneously anointing his guests with nard, while Jesus similarly interprets the actions of the woman who anoints His head as a foretelling of his burial." 71 These are only a few of the references that appear in Petronius' works. There are considerably more parallels (references to the Last Supper, the crowing of a rooster as the harbinger of betrayal, ridiculing a woman who is kissing wounds,

He was considered a judge of good taste and, if he did not consider something fancy, elegant, or nice, then it was not. Since he was jealous [of Petronius], Tigellinus embroiled him a conspiracy... Petronius did not want to take his life by violence; instead, he severed his veins, tied them together, and ordered that they be undone. Having been surrounded by a group of friends, he chatted with them, but not about serious matters like the immortality of the soul or philosophical ideas; instead, he ordered them to recite poems faintly... And contrary to the majority of those who died, he did not try to flatter Nero in his will, but rather describe the accounts of his debauchery with young freed slaves and prostitutes, even to the point of naming names. As he breathed his last breath, after having sealed his will with his consular insignia ring, Petronius sent it to Nero... Nero was terrified upon seeing that the secrecy of his night had been penetrated. Plutarch and Pliny support this detail, and they both say that Petronius crushed a precious goblet that he owned before he died because he did not want it to makes it way into Nero's greedy hands. Plutarch called Petronius 'Titus"; Idem, "Wstęp," in: Petroniusz, Uczta Trymalchiona, 2-3; http://biblioteka.kijowski.pl/ antyk\%20rzymski/06\%20petroniusz\%20gajusz\%20\%60arbiter\%60\%20-\%20 uczta \%20trymalchiona.pdf. Accessed 11.25.2020.

A. Socci, Wojna przeciwko Jezusowi, 169. According to L. Staff, The Banquet of Trimalchio is really "the most valuable and the most interesting preserved selfcontained story with the exception of the first realistic Roman novel Satyricon. The book is about the narrator Encolpius the freedman's adventures and Priap's wrath, which serves the plot in the same manner as Poseidon's anger in Odysseus by joining the parts loosely together. In what way Enclopius infuriated Priap cannot be deduced from the story. The time and place of the events have been determined in different ways: during Tiberius or Augustus' reign, in Naples or Cumae. The most probable proposition seems to be that it occurred during the final years of Claudius' or the first years of Nero's reign, in Puteola"; Idem, "Wstęp," in: Petroniusz, Uczta Trymalchiona, 2; http://biblioteka.kijowski.pl/ antyk\%20rzymski/06.\%20petroniusz\%20gajusz\%20\%60arbiter\%60\%20\%20 uczta\%20 trymalchiona.pdf. Accessed 11.15.2020. 
Fundamental Theology caricatures of crucified villains a deceased person who comes back to life, and the stupidity of those who believe it). Ancient historians note that the Roman playwright acts as if he knew Mark's Gospel perfectly and parodied it. Thirty years after Jesus' death, Petronius uses the information about Jesus' death to create a satire based on it. "It is difficult to believe that such a blatantly anti-Christian parody filled with references to the life of Jesus has eluded the notice of critics for centuries. Perhaps this oversight is driven by the assumption that a work from $65 \mathrm{AD}$ 'could not' contain references to passages from the Gospels. For, the Gospels 'could not' have been written by then. And because the facts are a bone in the critics throat, then so much the worse for the facts." 72

Do the Roman writer's works really contain hidden truths about Christianity, and are they a testament to the historicity of Jesus? A translator of Petronius' works has a completely different opinion. L Staff (d. 1957) states, "Some claimed that works such as Satyricon [...] were to a form of revenge on Nero-an attack disguised as a romance that uses a hidden key and pseudonyms to depict the emperor and his court. Voltaire called this conjecture le comble de l'absurdite, and many scholars staunchly dismiss him and consider Petronius' works simply as a portrayal of Rome during its collapse by referring to Macrobius, who lived when the secrets of these writings had not yet disappeared entirely. Macrobius speaks of the Satyricon as an entertaining novel created only to please. In any case, it is a picturesque and amusing story created by a man who knew how to observe and command his people to speak according to their class and profession. It is written in the colloquial language of the educated class of the time and interspersed with the southern folk dialect of the emancipated, which is not entirely clear, but skillfully stylized, full of common words, phrases, grammatical errors, and idioms that today are a main source of knowledge about vulgar Latin, particularly proverbs and manners of speaking. The work shines with humor and it is full of jokes as well as swarming with varied and fun adventures, which capture and sustain the reader's interest until the very end." 73 In this instance, A. Socci reads too much into the Roman writer's work and tries too hard to find hidden Christian content in it.

72 Ibid., 174-175.

73 L. Staff, "Wstęp," in: Petroniusz, Uczta Trymalchiona, 3-4; http://biblioteka. kijowski.pl/antyk\%20rzymski/ 06.\%20petroniusz\%20gajusz\%20\%60arbiter\%60\%20-\%20uczta\%20trymalchiona.pdf. Accessed 11.25.2020. 
Christianity spread freely until $65 \mathrm{AD}$, when Petronius left the emperor's court. The following year, he was forced to commit suicide. The persecution of the stoic ruling class that sympathized with Christianity that had occurred until then would change into a bloody war waged against Christ's followers. Nero married Poppaea Sabina, who-as Flavius records-sympathized with the Jews and influenced Nero's decisions. From 62-66 AD, Nero issued a decree against Christians, the evidence which can be found on the Nazareth Stone. When issuing this edict, the emperor took into the account the lie perpetrated by the Temple leaders who suggested that Jesus' followers stole His body from the grave and claimed that the entire story about His resurrection was a lie. A Socci calls Nero's edict explosive. The text was inscribed on a marble tablet that is $61 \mathrm{~cm}$ high, $38 \mathrm{~cm}$ wide, and 8.6-2.5 $\mathrm{cm}$ deep. The inscription is comprised of 22 lines. The stone was found in $1 \mathrm{AD}$ and reads as follows: "It is my decision [concerning] graves and tombs-whoever has made them for the religious observances of parents, or children, or household members-that these remain undisturbed forever. But if anyone legally charges that another person has destroyed, or has in any manner extracted those who have been buried, or has moved with wicked intent those who have been buried to other places, committing a crime against them, or has moved sepulcher-sealing stones, against such a person, I order that a judicial tribunal be created, just as [is done] concerning the gods in human religious observances, even more so will it be obligatory to treat with honor those who have been entombed. You are absolutely not to allow anyone to move [those who have been entombed]. But if [someone does], I wish that [violator] to suffer capital punishment under the title of tomb-breaker." 74 Needless to say, this degree does not really concern those who break into tombs and disturb the dead. Drawing on the E. Grzybek, M. Sardi's research, A. Socci states that the edict was really a charge against anyone who offended the gods. And, as Tertullian points out in his Apology, Christians belonged to precisely this category in the Roman Empire during Nero's reign. ${ }^{75}$

During the second century, Christians were known as hominis cultores, meaning worshippers of man. Therefore, the emperor's order was directed at Christians, since they were being accused of stealing Jesus' body from His place of burial and worshipping the dead man as a god. Socci thus concludes: "It seems obvious that this edict, which

74 Ibid., 178-179. For the content of the inscription, see F. Cumont, "Un Rescrit Impérial sur la Violatin de Sépulture,” Revue Historique CLXIII (1930): 241. 
Fundamental Theology

was issued at the turn of $62 \mathrm{AD}$, was [directed] against Christians. This also explains why the punishment for anyone who desecrated a grave, which had previously been a fine, was so severe. It also explains why the decree was retroactive and, apparently, targeted those who had already committed such a crime." 76 The content of the edict indicates clearly that Nero knew the accusations that the Jews in Jerusalem had made against the apostles, which is also is why the decree is so resolute regarding the issue of the removal of seals from graves. The appearance of the edict also indicates that neither Seneca nor Petronius was advising the emperor, but rather those who clearly inspired anti-Christian acts and sympathized with the Jews. Socci emphasizes that "The inscribed tablet would, therefore, be the oldest pagan document commemorating the zealous disputes about Jesus' resurrection that broke out in Jerusalem and reached Rome. At the center of these debates was this objective fact: the tomb to which Peter sent the inhabitants of Jerusalem was empty (Acts 2:29-31)."77

One should exercise some caution regarding this source because "the inscription has been the subject of many discussions that have continued to today." "78 The historian P. Janiszewski (b. 1967) notes that "according to some researchers, the Roman authorities could have supported the Jewish version of events according to Matthew [i.e., the body of Jesus was stolen by Jesus' disciples], which [this] inscription suggests-an inscription that was connected at some point with Jesus' resurrection and is regarded at times today as an example of the empire's reaction to Christian stories about the resurrection." ${ }^{79}$ In reality, however, this imperial decree should not be associated with Jesus' resurrection, even though it points to the interesting context

$76 \quad$ A. Socci, Wojna przeciwko Jezusowi, 181.

77 Ibid., 182.

78 P. Janiszewski, "Pierwsze polemiki wokół zmartwychwstania i losów ciała Jezusa w kontekście rzeczywistości praktyk grzebalnych epoki," Przegląd Historyczny 100(2009): 424. "The inscription is well preserved on a marble slab that measures 60 by $37.5 \mathrm{~cm}$. Franz Cumont first published the text in 1930. The location where this monument was found is unknown. When the inscription was published, the marble slab was being preserved in the Cabinet des Médailles in Paris' National Library, where it was found in 1925, and is from the collection of Wilhelm Fröhner. In the inventory of this collection, it is noted that the slab was brought from Nazareth in 1878 AD (dalle de marbre envoyée de Nazareth en 1878)"; Ibid., 422-423. 


\section{[from which the decree arose]. ${ }^{80}$ The historian emphasizes: "The harsh}

$80 \quad$ P. Janiszewski emphasizes, "Jerôme Carcopino pointed out that the aforementioned note from Fröhner's catalogue reveals only that the inscription was brought from Nazareth, and not that it was found there. In the $19^{\text {th }}$ century, outside of Jerusalem Nazareth was the main location for the antiquities market where people could purchase ancient items brought from different places throughout the entire region. In addition, it was not until $44 \mathrm{AD}$ that Galilee became part of the Roman Empire, so the inscription could not have been made in Nazareth before then. The stone could have come from any place that is suited to its date and character; studies conducted later have surmised the various places from which it could have originated (Samaria, Decapolis, Jerusalem, etc.). When the inscription was written is known: paleography indicates the second half of the first century BC or first century AD, since the style is very characteristic of

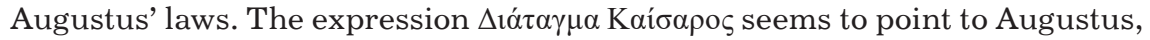
but Caesar, Tiberius, Claudia, Nero, etc. were also considered during the course of the study. (F. E. Brown even dated the inscription to the reign of Hadrian). Researchers do not agree about the character of the text. Some of them claim that the inscription contains modifications to the ruler's edict. Fernand de Visscher asserts that line 1 lacks the complete title and, therefore, indicates that the inscription is unofficial and private. Lines 2-18 contain the emperor's decree, and lines 10-22 are not part of the emperor's writing. James H. Oliver does not agree entirely with this; he states that the text is a collection of different writings, but that the last verse, which mentions the death penalty for anyone who desecrates a grave, must not be "private," all the more so, since the death penalty for such an office seems very serve: fines for such crimes were imposed in the era of the early empire. According to Oliver the text that is known from the inscription consisted of a petition that the Jews might have sent to Caesar, his response, and the interdict of some provincial representative of the Roman authorities. Later studies of the text went in different directions, but we are interested in only one: the relationship between Jesus' resurrection that some have postulated and, more broadly, Christian-Jewish-pagan polemics on this topic. Franz Cumont (and E. Cuq) generally dates the inscription to the reign of Augustus, meaning $45 \mathrm{AD}$, but at the end of his publication he adds that it could be connected with Tiberius as an eventual possibility. F. M. Abel and M. J. Lagrande, L. Cerfaux, and E. Schönbauer also think that the inscription is linked to Tiberius. The suggestions support the assertion that the inscription, which supposedly comes from Nazareth, refers directly to Jesus. Since this text threatens anyone who removes a body from the grave and takes it to another place with death, then it allegedly confirms the Jewish version of the story about how Jesus' body was stolen by his disciples, which is known from Matthew's account. According to this interpretation, the Jews and those who they bribed reported to Pilate that the disciples had stolen Jesus' body. Because this involved the body of a man who was accused of revolting against the Roman Empire, the governor wrote to Tiberius, who ordered that the guilty parties be put to death. Other researchers such as G. De Sanctis and M. Guarducci modified this theory. De Sanctis admits that the inscription would not have been erected in Nazareth during Tiberius' reign because Galilee was not under direct Roman rule. For this reason, the scholar toned down the sensational dimension of the theory but upheld the connection between the inscription and Jesus' resurrection. In his opinion, the inscription was written during the 
Fundamental Theology

character of this law could have been a reaction to some abominations that were occurring somewhere else. For, the bodies of the dead, particularly convicts, were used for magical practices (which themselves were punishable by death!). Bodies of prisoners who were executed cruelly were particularly valuable because [it was believed] that they became evil, vindictive, powerful demons after they died, and were, therefore, the most effective at what they did." 81

Apart from Petronius' Satyricon, A. Socci also mentions other satirical works that parody Christianity such as Chaereas and Challirhoe by Chariton of Aphrodisias (d. cir I/II cent.). ${ }^{82}$ This work was written at the turn of two imperial eras: Nero's and Hadrian's. Researchers have observed that the work contains allusions to the story of Jesus. According to Socci, "The text contains the motif of Chaereas' crucifixion (between two thieves). He is invited to come down from the cross with the same mocking words that the passerby addressed to Jesus in the Gospel (Mt 27:40). It also contains many other details that are connected to descriptions of the Lord's Passion in the Gospels. Chariton depicts Chaereas' seeming death, the "theft of [his] body' (although he was really still alive), and the discovery of the empty tomb. In short, the romance teems with parodical references to the Gospel." ${ }^{83}$ In addition, A. Socci emphasizes that the Greek text of this work is similar to passages from St. Mark and St. John's Gospels.

Based on an analysis of these sources, the Italian journalist comes to the conclusion that the works of Jesus were well known in the world of pagan culture during the 60's $\mathrm{AD}$. Referring to the biased research

reign of Claudius, and, according to Suetonius (Claudius 25.4), 'Since the Jews constantly sowed discord at the instigation of Chrestus, he expelled them from Rome' (Iudeos impulsore Chresto assidue tumultuantes Romam expulsit). It was then that disputes about the resurrection began and the emperor, by the order that we know from the inscription, appeared to oppose the Christians, who he did not distinguish from the Jews. F. de Zuluet strongly argues in favor of this impressive idea by showing that the text is not connected with Jesus but rather with Augustus' policies. E. Grzybek and M. Sordi, on the other hand, connect the text with the Christians but think that inscription was made during Nero's persecution of the Christians. A Giovannini and M. Hirt have sought to show the relationship between the inscription and Augustus by connecting it with the policy that this emperor carried out after the victory at Actium. Theirs is the most sensational explanation of the phenomenon of this inscription"; Ibid., 424-426.

Ibid., 427.

Chariton was a Greek writer and the author of the oldest preserved Greek romance, the e-book novel Chaereas and Callirhoe; cf. Stownik kultury antycznej, 92 . 
of a set of historians who he has chosen, Socci asserts that the ancient authors saw Christianity in an exceptionally positive light and that a period of persecution began it was only when Nero ascended the throne. Unfortunately, an objective analysis of the sources does not arrive at such optimistic conclusions. For, apart from Tacitus' Annals, the documents to which Socci refers cannot withstand criticism and are not credible.

\section{Classical Non-Christian Sources}

Since the end of the first century, ancient authors directly and overtly described Christians in their writings. We can find these descriptions in Suetonius' (d. cir. 140 AD) De Vita Caesarum. When writing the biography of Claudius, who ruled from 41-54 AD, the historian mentions the edict of expulsion ('Since the Jews constantly sowed discord at the instigation of Chrestus, he expelled them from Rome'). ${ }^{84}$ When analyzing this passage, A. Socci draws the following conclusions: "I would like to highlight three astounding issues: first, a flourishing community of Christians lived (15-20 years after the crucifixion) in the imperial capital as early as $49 \mathrm{AD}$ (Orosius dates the decree to this year); secondly, 'Suetonius writes about Jesus Christ as the source of the discord - that is, the cause of dispute within the Roman Jewish community;' thirdly, and most importantly, Suetonius "perceives Christ as the instigator who is alive in an age of events." 85 In this way, Jesus was considered to be a living person in Rome in the 40s AD. Peter brought faith in the Person [of Christ] to the Eternal City, where he proclaimed the Gospel very openly around the year $41 \mathrm{AD}$. Tacitus confirms that different social groups from the elite to slaves readily received the Good News. ${ }^{86}$ This lasted until $62 \mathrm{AD}$, when Nero issued the edict that brought to an end the Christians' ability to freely carry out their mission to evangelize in Rome, which had been possible since $41 \mathrm{AD}$.

The most comprehensive account of Jesus from the second century is contained in the writings of Pliny the Younger (61-113). As the

84 The first passage appears in Nero's biography: "Punishment was inflicted on the Christians, a class of men given to a new and mischievous superstition," and the second pertains to Claudius, "Since the Jews constantly made disturbances at the instigation of Chrestus, he expelled them from Rome," Suetonius, The Twelve Caesars, https://penelope.uchicago.edu/Thayer/E/Roman/Texts/ Suetonius/12Caesars/Nero*.html. Accessed 12.06.2020. 
governor of Bithynia, this imperial official observed up close how the "plague" of Christianity spread (111-113 AD). Observing what was happening, he consulted Emperor Trajan about this matter. ${ }^{87}$ Pliny

Fundamental Theology
87

"It is my invariable rule, Sir, to refer to you in all matters where I feel doubtful; for who is more capable of removing my scruples, or informing my ignorance? Having never been present at any trials concerning those who profess Christianity, I am unacquainted not only with the nature of their crimes, or the measure of their punishment, but how far it is proper to enter into an examination concerning them. Whether, therefore, any difference is usually made with respect to ages, or no distinction is to be observed between the young and the adult; whether repentance entitles them to a pardon; or if a man has been once a Christian, it avails nothing to desist from his error; whether the very profession of Christianity, unattended with any criminal act, or only the crimes themselves inherent in the profession are punishable; on all these points I am in great doubt. In the meanwhile, the method I have observed towards those who have been brought before me as Christians is this: I asked them whether they were Christians; if they admitted it, I repeated the question twice, and threatened them with punishment; if they persisted, I ordered them to be at once punished: for I was persuaded, whatever the nature of their opinions might be, a contumacious and inflexible obstinacy certainly deserved correction. There were others also brought before me possessed with the same infatuation, but being Roman citizens, I directed them to be sent to Rome. But this crime spreading (as is usually the case) while it was actually under prosecution, several instances of the same nature occurred. An anonymous information was laid before me containing a charge against several persons, who upon examination denied they were Christians, or had ever been so. They repeated after me an invocation to the gods, and offered religious rites with wine and incense before your statue (which for that purpose I had ordered to be brought, together with those of the gods), and even reviled the name of Christ: whereas there is no forcing, it is said, those who are really Christians into any of these compliances: I thought it proper, therefore, to discharge them. Some among those who were accused by a witness in person at first confessed themselves Christians, but immediately after denied it; the rest owned indeed that they had been of that number formerly, but had now (some above three, others more, and a few above twenty years ago) renounced that error. They all worshipped your statue and the images of the gods, uttering imprecations at the same time against the name of Christ. They affirmed the whole of their guilt, or their error, was, that they met on a stated day before it was light, and addressed a form of prayer to Christ, as to a divinity, binding themselves by a solemn oath, not for the purposes of any wicked design, but never to commit any fraud, theft, or adultery, never to falsify their word, nor deny a trust when they should be called upon to deliver it up; after which it was their custom to separate, and then reassemble, to eat in common a harmless meal. From this custom, however, they desisted after the publication of my edict, by which, according to your commands, I forbade the meeting of any assemblies. After receiving this account, I judged it so much the more necessary to endeavor to extort the real truth, by putting two female slaves to the torture, who were said to officiate' in their religious rites: but all I could discover was evidence of an absurd and extravagant superstition. I deemed it expedient, therefore, to adjourn all further proceedings, in order to 
the Younger thought that the Christian faith threatened the stability of the Roman Empire, which he believed was made possible through polygamy. Therefore, he persecuted and tortured Christians in order to force them to confess or renounce their faith. Trajan consented to Governor Pliny's methods, but he did not order him to specifically seek out Christians. ${ }^{88}$

We know about the Samaritan Tallus' (a freed slave of Tiberius Caesar) writings that relate the events of history from the fall of Troy to the middle of the first century $\mathrm{AD}$ and describe what occurred after Jesus died (darkness came over the whole land) only through the references to them contained in the writings of Josephus Flavius ${ }^{89}$ and Sextus Julius Africanus (d. cir. 242). ${ }^{90}$ Julius cites these writings in his work Chronology, which has not survived to this day. Fortunately, quotations contained in other works make it possible to identify these lost references. A Socci states, "Julius Africanus proves that Tallus' naturalistic interpretation is not true- the eclipse could not have happened during

consult you. For it appears to be a matter highly deserving your consideration, more especially as great numbers must be involved in the danger of these prosecutions, which have already extended, and are still likely to extend, to persons of all ranks and ages, and even of both sexes. In fact, this contagious superstition is not confined to the cities only, but has spread its infection among the neighbouring villages and country. Nevertheless, it still seems possible to restrain its progress. The temples, at least, which were once almost deserted, begin now to be frequented; and the sacred rites, after a long intermission, are again revived; while there is a general demand for the victims, which till lately found very few purchasers. From all this it is easy to conjecture what numbers might be reclaimed if a general pardon were granted to those who shall repent of their error." Gaius Plinius Caecilius Secundus, "I-To Septittus," Letters of Pliny, ed. F. C. T. Bosanquet, trans. William Melmoth, Project Gutenberg, 2016. E-book. https://www.gutenberg.org/files/2811/2811-h/2811-h. htm. Accessed 12.8.2020.

"You have adopted the right course, my dearest Secundtis, in investigating the charges against the Christians who were brought before you. It is not possible to lay down any general rule for all such cases. Do not go out of your way to look for them. If indeed they should be brought before you, and the crime is proved, they must be punished; with the restriction, however, that where the party denies he is a Christian, and shall make it evident that he is not, by invoking our gods, let him (notwithstanding any former suspicion) be pardoned upon his repentance. Anonymous informations ought not to be received in any sort of prosecution. It is introducing a very dangerous precedent, and is quite foreign to the spirit of our age. Ibid., "XCVIII-Trajan to Pliny," Letters of Pliny. uchicago.edu/josephus/ant-18.html. Accessed 12.07.2020. 
Fundamental Theology

the full moon (that took place during the Jewish Passover when Jesus was crucified)." ${ }^{11}$ However, because of its historicity, Tallus' speech is the most valuable. Around $50 \mathrm{AD}$, this pagan author comments on Jesus' extraordinary death from a secular point of view. This indicates that a "text devoted to these events [was circulated] in the imperial circles of that time." 92 When commenting on this text, Julius Africanus thinks that Tallus' interprets the darkness incorrectly, but he considers his testimony itself to be essential." A Socci adds that, "Honesty demands that we consider this text irrelevant because we know neither the author nor the year in which he wrote it, and we know about his writings only indirectly." ${ }^{3}$

Among other writers of pagan antiquity who wrote about Christianity-often critically and maliciously, Socci mentions in passing only the philosopher Epictetus of Hierapolis (who died during Hadrian's reign from 117-138 AD) and his work Diatribe; Marcus Aurelius (d. cir. $180 \mathrm{AD}$ ) and his Reminiscences; Galena (130-200 AD); Marcus Cornelius Fronto (d. cir. 166 AD) who wrote the critical speech "Against Christians"; the satirist Lucian of Samosata (d. cir. 200) who wrote two ironic works; Apuleius of Madaurensis (d. after 170 AD) who mocked Christians in his Metamorphoses written around $160 \mathrm{AD}$; and Porifirus (d. cir. $305 \mathrm{AD}$ ) and Celsus of Alexandria (d. $3^{\text {rd }}$ cent.), who launched the most direct and systematic attack on Christianity.

A. Socci also mentions a pagan document—namely, a letter written by the first-century Syrian stoic Mara Bar-Serapion. ${ }^{94}$ This philosopher, who was imprisoned by the Romans, wrote a letter to his son, Serapio, encouraging him "to seek wisdom always, even if it brings hostility and persecution upon him [a situation in which Bar-Serapion found himself], since history proves that triumph and glory await

A. Socci, Wojna przeciwko Jezusowi, 191.

Ibid.

Ibid., 192.

"For what advantage did the Athenians gain by the murder of Socrates, the recompense of which they received in famine and pestilence? Or the people of Samos by the burning of Pythagoras, because in one hour their country was entirely covered with sand? Or the Jews by the death of their wise king, because from that same time their kingdom was taken away? For with justice did God make recompense to the wisdom of these three: for the Athenians died of famine; and the Saminians were overwhelmed by the sea without remedy; and the Jews, desolate and driven from their own kingdom, are scattered through every country. Socrates is not dead, because of Plato; neither Pythagoras, because of the statue of Juno; nor the Wise King, because of the laws which he promulgated." W. Cureton, Spicilegium Syriacum, London 1855, 73-74. 
precisely those who are just and love truth.""95 Within this context, Mara Bar-Serapion refers to the "wise Jewish king" and the destruction of Jerusalem as a punishment for his crucifixion. Historians date this document to the year $73 \mathrm{AD}$ because it describes the event as occurring soon before and stemming strongly from the climate of that time. The author himself is certainly not a Christian because he writes about "our gods" and is a proponent of the ideas of Stoicism. In Mara Bar-Serapion's opinion, Jesus continues to live through his teachings Fundamental and not because he resurrected from the dead. Nevertheless, three aspects of this letter deserve particular attention. Firstly, it is clear that Jesus made a huge impression on his contemporaries, which is evidenced by the fact that he is mentioned alongside Socrates and Pythagoras. He certainly was not a "marginal Jew" to this stoic. Secondly, in order to write about Jesus, Mara must have known the texts about his life and teaching well. In this instance, A. Socci concludes that certain versions of the Gospels must have been circulating among the inhabitants of the Roman Empire. It appears that the philosopher's son also knew about Jesus and his "new law." Thirdly, one can clearly see in this work the admiration and respect that those who represented stoic culture had for Jesus; for, they were interested in his teachings but denied a priori his divinity and resurrection.

Another source that Socci quotes in order to confirm the historicity of Jesus is Testimonium Flavianum, which can be found in Josephus Flavius' Antiquities of the Jews. ${ }^{96}$ This Jewish work was written around $93 \mathrm{AD}$, and scholars have argued whether Flavius' testimony about Jesus is authentic since the dawn of modernity. ${ }^{97}$ These scholars have accused early Christian writers of editing the writings in such a way that Flavius' testimony is too favorable to Jesus. The Italian journalist points out that, "even if 'we purify' the Testimonium of all Christian interpolations, we will not find anything in it that would prove that the

$95 \quad$ A. Socci, Wojna przeciwko Jezusowi, 195.

96 "Now there was about this time Jesus, a wise man; if it be lawful to call him a man. For he was a doer of wonderful works; a teacher of such men as receive the truth with pleasure. He drew over to him both many of the Jews, and many of the Gentiles. He was [the] Christ. And when Pilate, at the suggestion of the principal men among us, had condemned him to the cross; those that loved him at the first did not forsake him. For he appeared to them alive again, the third day: as the divine prophets had foretold these and ten thousand other wonderful things concerning him. And the tribe of Christians, so named from him, are not extinct at this day." Josephus Flavius, The Antiquities of the Jews, XVIII.3.3, http://penelope.uchicago.edu/josephus/ant-18.html. Accessed 12.07.2020. 
information about the resurrection that Christians propagated among the people is either the true or the official version of the Temple leaders (that the Christians had stolen the body)." ${ }^{98}$ Having obtained firsthand information about Christians, the Jewish historian did not contradict their claims or calumniate Jesus. Socci continues: "Moreover, he even acknowledges Jesus' miracles (even the most fervent critics did not call into question [Flavius'] authenticity regarding this passage) and, unlike the high priests, he did not consider them 'witchcraft' (i.e., preternatural, satanic phenomena)." 99 The Italian journalist expresses his admiration for Flavius' testimony and asserts that no Christian scribe would ever write anything like it. Socci emphasizes that, by calling Jesus the Messiah (but in the past tense), Josephus Flavius desired"as he did in all of his works"-to dissuade his fellow countrymen from waiting for another savior and inciting messianic revolts during a time when the Roman Empire seemed to be the only guarantor of the peace for which they longed." 100 When writing about debates about Testimonium Flavianum, the Italian journalist ultimately asserts, "the exceptional quality of Josephus Flavius' testimony is incontrovertible and, for this reason, will always be a bone in the throat to 'rationalists.' For, it exposes the shocking irrationality of both their approach and the views that they promote and calls their axioms into question."101

A presentation of Jewish sources would not be complete without mentioning the Talmud. ${ }^{102}$ When quoting specific passages about the condemnation, passion, and death of Jesus, Socci refers to the French historian J. Genot-Bismuth (d. 2004) and notes that, in the Talmud, "the Jewish reconstruction of events' shockingly coincides with St. John's Gospel, 'such that the two works mutually confirm each other and simultaneously suggest that they refer to a tradition that relies on the testimony of eyewitnesses." ${ }^{103}$ In addition, the Talmud does not deny that Jesus performed miracles, but rather that the false Messiah performed them in the name of God, so his works were witchcraft. Like

$98 \quad$ A. Socci, Wojna przeciwko Jezusowi, 231.

$99 \quad$ Ibid., 232.

Ibid., 233.

Ibid., 242.

102 M. S. Wróbel, "Krytyka tekstologiczna i historyczna passusów Talmudu o Jezusie i chrześcijaństwie," in: Jezus i chrześcijanie $w$ źródtach rabinicznych. Perspektywa historyczna, społeczna, religijna i dialogowa, eds. K. Pilarczyk, A. Mrozek, Kraków 2012, 15-50; Idem, Jezus i Jego wyznawcy w Talmudzie. Analiza tekstologiczna, historyczna i socjologiczna, Lublin 2013. 
Josephus Flavius, Socci concludes here that, among other things, the Talmud confirms the credibility of the Gospel by meticulously enumerating the accusations made against Jesus." 104

When summarizing the views of pagan and Jewish sources that refer to Jesus, Socci emphasizes that this documentation is immense. Therefore, one cannot assert that Jesus was an irrelevant figure in the history of his own country or the entire world. A. Socci concludes, "What we have discovered up to now proves the opposite. It is sufficient to look at other spiritual figures from that era (from the Giver of the Law [Moses] to John the Baptist, from Hillel to Simon Bar-Kochba, or the Egyptian - the leader of four thousand assassins who is mentioned in the Acts of the Apostles (Acts 21:38)), and see that their achievements have echoed into the present age far less than Jesus'. After all, we are speaking here only about the small number of documents that have survived the storms of history to the present day. [...] Such a wealth of texts is shocking, especially since there is no reason for it. As historians have explained, everything suggests that Jesus' activity did not resonate among Christian authors. And yet, as we have seen, non-Christian sources not only confirm what we know about Jesus' life, they also testify to three important factors: miracles (that obviously are presented in an unfavorable light), 'claims' to divinity, and the disappearance of Jesus' body from the tomb (even Josephus Flavius writes about the resurrection)." 105

\section{Conclusion}

Substantiating the historicity of Jesus is the focus of Antonio Socci's early apology. The Italian apologist first presents his methodological comments on research that has been conducted, and then he introduces his analysis of specific sources. It is surprising that the journalist who is not educated in theology examines the New Testament texts and ancient non-Christian literature so deeply. As he himself admits, he refers to the studies of specialists in the field. A. Socci does make mistakes, however. In this conclusion of my analysis of A. Socci's apology on Jesus, I would like to formulate three conclusions.

Firstly, when dealing with the historicity of the Gospel accounts, A. Socci Po refers to the category of testimony. Although he does not cite the latest research, he highlights essential aspects of this issue. His analyses are logical. Socci covers the entire process of how the

104 Ibid., 240.

105 Ibid., 254-255. 
Gospels developed, and he clearly draws out and highlights the category of eyewitnesses. ${ }^{106}$

Secondly, with regard to non-Christian sources, the Italian journalist makes a clear distinction. He presents and interprets the classical texts (Tacitus, Suetonius, Pliny the Younger, Mara Bar Serapion, Josephus Flavius, and the Talmud) correctly. His analyses include the entire anFundamental cient context and are grounded in historical realities. When analyzing Theology additional non-Christian sources, Socci is clearly influenced by specific historians and goes too far in interpreting their analyses. He does not make a surficial critical examination of these sources, and he takes certain assumptions and research hypotheses for granted. As a result, he the number of non-Christian sources that contain testimonies about Jesus is erroneously higher than it should be and their historical value remains questionable. When trying to make the substantiations that Socci does, one should rely instead on credible sources so as to not to ridicule the figure of Jesus. ${ }^{107}$

Thirdly, A. Socci clearly makes anti-ideological arguments in his defense of Christ. He is aware of current attacks on the Master of Nazareth and, for this reason, emphasizes the historical value of sources. Even though Socci's apology has considerable substantive value, it contains too many subjective arguments. ${ }^{108}$

\section{Bibliography:}

1. Apokryfy Nowego Testamentu. Ewangelie apokryficzne. Edited by M. Starowieyski. Volume 1. http://www.opoka.org.pl/biblioteka/T/TB/ apokryfy-04.html. Accessed 11.25.2020.

2. Artemiuk, P. Renesans apologii. Płock 2016.

3. Carmignac, J. Początki Ewangelii synoptycznych. Kraków-Mogilany 2009.

4. Cumont, F. "Un Rescrit Impérial sur la Violatin de Sépulture." Revue Historique CLXIII(1930).

5. Cureton, W. Spicilegium Syriacum. London 1855.

106 Cf. H. Witczyk, "Wiarygodność historyczna Ewangelii - nowe kierunki badań," in:Historia-wiara-nauka.Źródła poznania Jezusa Chrystusa, ed.P.Artemiuk, Płock 2018, 70-116.

107 Cf.M. Skierkowski, "Problemy i perspektywy współczesnych badań nad źródłami poznania Jezusa Chrystusa," in: Historia - wiara - nauka. Źródła poznania Jezusa Chrystusa, Płock 2018, 7-69. H. Seweryniak, "Apologia historyczności Ewangelii kanonicznych," in: Historia-wiara-nauka. Źródta poznania Jezusa Chrystusa, Płock 2013, 116-166.

108 P. Artemius, ed., Historia - wiara - nauka. Źródta poznania Jezusa Chrystusa, Płock 2018. 
6. Flavius, Josephus. The Antiquities of the Jews. http://penelope.uchicago. edu/josephus/ant-18.html. Accessed 12.07.2020.

7. Flew, A., Varghese, R. A. Bóg istnieje. Dlaczego najstynniejszy ateista zmienit swój światopoglad? Warszawa 2010.

8. Gaius Plinius Caecilius Secundus. Letters of Pliny. Edited by F. C. T. Bosanquet. Translated by William Melmoth. Project Gutenberg, 2016. Ebook. https://www.gutenberg.org/files/2811/2811-h/2811-h.htm. Accessed 12.8.2020.

9. Historia - wiara - nauka. Źródta poznania Jezusa Chrystusa. Edited by Fundamental P. Artemiuk. Płock 2018.

10. Jacoby, F. Die Fragmente der griechischen Historiker. II B. Leiden 1962.

11. Janiszewski, P. "Pierwsze polemiki wokół zmartwychwstania i losów ciała Jezusa w kontekście rzeczywistości praktyk grzebalnych epoki.” Przeglad Historyczny 100(2009): 407-435.

12. Justyn Męczennik, 1 i 2 Apologia. Dialog z Żydem Tryfonem. Translated and compiled by L. Misiarczyk. Warszawa 2012.

13. Kudasiewicz, J., Witczyk, H. Jezus i Ewangelie w ogniu dyskusji. Od H. Reimarusa do T. Polaka. Kielce 2011.

14. Obrycki, K. ed. trans. "Apokryficzna korespondencja między Seneką i świętym Pawłem." Warszawskie Studia Teologiczne 10(1997): 219-240.

15. Pascal, B. Myśli. Compiled by T. Żeleński (Boy). Warszawa 1989.

16. Petroniusz. Uczta Trymalchiona. http://biblioteka.kijowski.pl/antyk\%20 rzymski/06\%20petroniusz\%20gajusz\%20\%60arbiter\%60\%20-\%20ucz ta\%20trymalchiona.pdf.

17. Pietras, H. Poczattki teologii Kościoła. Kraków 2007.

18. Seweryniak, H. "Apologia historyczności Ewangelii kanonicznych." In: Historia - wiara - nauka. Źródta poznania Jezusa Chrystusa. Edited by P. Artemiuk. Płock 2018, 116-166.

19. Skierkowski, M. Uczłowieczony Bóg. Chrystologia fundamentalna. Płock 2013.

20. Skierkowski, M. "Problemy i perspektywy współczesnych badań nad źródłami poznania Jezusa Chrystusa." In: Historia - wiara - nauka. Źródta poznania Jezusa Chrystusa. Edited by P. Artemiuk. Płock 2018, 7-69.

21. Socci, A. Ci, którzy wrócili z zaświatów. Kraków 2014.

22. Socci, A. Czas burzy. Dramat czasu konklawe. Kraków 2013.

23. Socci, A. Czy to naprawdę Franciszek? Kościót w czasach zamętu. Kraków 2015.

24. Socci, A. Kościót czasu Antychrysta. Kraków 2020.

25. Socci, A. Ostatnie proroctwo. List do papieża Franciszka o Kościele w czasach ostatecznych. Kraków 2016.

26. Socci, A. Śledztwo $w$ sprawie Jezusa. Kraków 2010.

27. Socci, A. Tajemnica Benedykta XVI. Dlaczego pozostat papieżem? Kraków 2019.

28. Socci, A. Wojna przeciwko Jezusowi. Kraków 2012.

29. Starowiejski, M. ed. Apokryfy Nowego Testamentu. Ewangelie apokryficzne. Volume 1. http://www.opoka.org.pl/biblioteka/T/TB/apokryfy-04.html. 
Fundamental Theology
30. Suetonius. The Twelve Caesars. https://penelope.uchicago.edu/Thayer/E/ Roman/Texts/Suetonius/12Caesars/Nero*.html. Accessed 12.06.2020.

31. Szarmach, M. “'Listy, które czyta wielu.' Psuedokorespondencja św. Pawła z Seneką." Symbolae Philologorum Posnaniensium Graecae et Latinae 22(2012): 91-94.

32. Tacitus. Book XV. Par. 38. Annals. English translation can be found at: https:/penelope.uchicago.edu/Thayer/E/Roman/Texts/Tacitus/ Annals/15B*.html. Accessed 12.08.2020.

33. Tacyt. Wybór pism. Compiled by S. Hammer. Wrocław 2004.

34. Tertulian. "Apologetyk." In: Pisma Ojców Kościoła, Volume 20. Edited by J. Sajdak. Poznań 1947.

35. Wądołowski, Ł. Apologia Jezusa i Kościoła w pismach Antonia Socciego. Warszawa 2015.

36. Winniczuk, L. Pliniusz Młodszy w świetle swoich listów i mów. Warszawa 1987.

37. Winniczuk, L. ed. Stownik kultury antycznej. Warszawa 1988.

38. Witczyk, H. "Wiarygodność historyczna Ewangelii - nowe kierunki badań." In: Historia - wiara - nauka. Źródta poznania Jezusa Chrystusa. Edited by P. Artemiuk. Płock 2018, 70-116.

39. Wojciechowski, M. Czym sa Ewangelie. Kraków 2014.

40. Wróbel, M. S. "Krytyka tekstologiczna i historyczna passusów Talmudu o Jezusie i chrześcijaństwie.” In: Jezus i chrześcijanie w źródłach rabinicznych. Perspektywa historyczna, społeczna, religijna i dialogowa. Edited by K. Pilarczyk, A. Mrozek. Kraków 2012, 15-50.

41. Wróbel, M. S. Jezus i Jego wyznawcy w Talmudzie. Analiza tekstologiczna, historyczna i socjologiczna. Lublin 2013. 